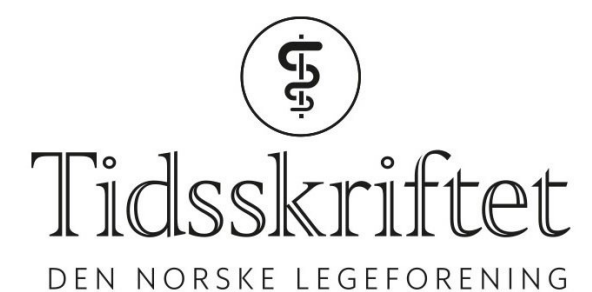

DEN NORSKE LEGEFORENING

\title{
Tvangsmedisinering og tvangsmiddelbruk ved psykoser
}

KOMMENTAR

\section{ULRIK FREDRIK MALT}

E-post: u.f.malt@medisin.uio.no

Ulrik Fredrik Malt er overlege og professor emeritus

Interessekonflikt: Malt er leder av Norsk psykiatrisk forening.

I artikkelen «Reservasjonsrett i psykiatrien nå!» reiser Merete Nesset \& Anne Grethe Teien krav om juridisk rett til å takke nei til psykiatrisk tvangsbehandling gjennom forhåndserklæringer.

Nesset \& Teien spør hvilke holdninger Norsk psykiatrisk forening har til kravet om reservasjonsrett mot tvangsmedisinering av pasienter med psykiske lidelser, underforstått akutte og kroniske psykoser. De tar også opp bruk av antipsykotika som et nødrettsbegrunnet tvangsmiddel.

Norsk psykiatrisk forening mener at enhver pasient, innen både somatisk og psykisk helse, har rett til å reservere seg mot en bestemt type behandling. Det gjelder også dersom pasienten ved å nekte behandlingen øker sannsynligheten for å bli varig ufør eller i verste fall $\mathrm{d} \emptyset$. All behandling, inkludert bruk av antipsykotika, skal derfor som en grunnregel være basert på informert samtykke.

Men å ta avgjørelser som kan ha alvorlige konsekvenser for fremtidig helse og funksjon krever at pasienten er orientert om fordeler og ulemper knyttet til valgene, både på kort og lang sikt. Pasienten må gis oppdatert kunnskap om hvilke behandlingstilbud som er tilgjengelige og deres effekter. Heri inngår orientering om psykoedukasjon og psykososiale intervensjoner, gjennomgang av antipsykotikas effekter, mulige bivirkninger og hvordan disse kan håndteres.

Det er situasjoner hvor det kan reises alvorlig tvil om pasienten faktisk forstår den orientering som gis og de konsekvenser for egen helse eventuelle valg vil ha. Norsk psykiatrisk forening har nedsatt et utvalg som arbeider med forslag til prosedyrer for vurdering av slike situasjoner (vurdering av samtykkekompetanse).

Man må skille mellom tvangsmedisinering og tvangsmidler. Tvangsmidler er akutte tiltak som kan brukes når det er uomgjengelig nødvendig for å hindre at pasienten skader seg selv eller andre. Tvangsmidler kan for eksempel være beltelegging eller enkeltstående bruk av korttidsvirkende legemidler. Hos enhver pasient som har en kronisk psykose bør det på forhånd foreligge en skriftlig avtale om hvilket tvangsmiddel som i ytterste nødsfall skal kunne brukes. Men slike avtaler foreligger etter vår erfaring sjelden. Nesset \& Teien mener at ved forhåndsreservasjon mot tvangsmedisinering, skal leger ikke bruke nødrett som 
begrunnelse for bruk av legemidler som tvangsmiddel. Men nødrett er nedfelt i norsk lov. I hvilken grad et bestemt tvangsmiddel iverksatt under henvisning til nødrett er forenlig med loven, er det domstolene som avgjør.

Hvis bruk av tvangsmiddel er uomgjengelig nødvendig, mener Norsk psykiatrisk forening at behandlere så langt som mulig bør ta hensyn til de ønsker pasienten har fremsatt. Men det er situasjoner hvor valgmuligheter av tvangsmidler kan være begrenset. Blant annet kan begrenset plass på en akuttavdeling så vel som utilstrekkelig tilgang på kvalifisert helsepersonell innskrenke valgmulighetene. En viktig oppgave for Norsk psykiatrisk forening er derfor også å bevisstgjøre politiker og helseforetak om denne sammenhengen. Foreningens ønske er at tvangsmiddelbruk i form av medikasjon kan reduseres til et absolutt minimum og at behandling av psykoser skal være basert på informert samtykke fra pasientens side.

Publisert: 21. august 2017. Tidsskr Nor Legeforen. DOI: 10.4045/tidsskr.17.0675

(C) Tidsskrift for Den norske legeforening 2020. Lastet ned fra tidsskriftet.no 